\title{
PENGARUH PENAMBAHAN SANTAN KELAPA TERHADAP KUALITAS DONAT
}

\section{Effect of Coconut Milk Addition to Donuts Quality}

\author{
Andina Kristy Novitasari ${ }^{1 *}$, Erni Sofia Murtini ${ }^{1}$ \\ Jurusan Teknologi Hasil Pertanian, FTP Universitas Brawijaya Malang \\ Jl. Veteran, Malang 65145 \\ *Penulis korespondensi, email: andinakristy@gmail.com
}

\begin{abstract}
ABSTRAK
Donat merupakan pangan olahan berbahan dasar tepung terigu, telur, gula, ragi, dan margarin yang difermentasikan dalam waktu tertentu dan digoreng dengan metode penggorengan menggunakan minyak banyak (deep frying). Donat memiliki bentuk seperti cincin. Metode penelitian yang digunakan ialah metode Response Surface Method (RSM) dengan desain rancangan one factor. Faktor yang dikaji yaitu konsentrasi penambahan santan kelapa $\left(\mathrm{X}_{1}\right)$ dan respon yang akan dioptimasi yaitu kualitas donat dengan menggunakan pengukuran kekerasan $\left(R_{1}\right)$, cohesiveness $\left(R_{2}\right)$ dan springiness $\left(R_{3}\right)$ pada penyimpanan selama 4, 24, dan 48 jam. Konsentrasi santan kelapa yang ditambahkan yaitu, $0 \%, 15 \%, 30 \%, 45 \%$, dan $60 \%$. Hasil penelitian menunjukkan bahwa penambahan santan kelapa berpengaruh terhadap kualitas donat. Konsentrasi penambahan santan kelapa optimum yaitu $30.48 \%$ dengan profil tekstur kekerasan sebesar $15.62 \mathrm{~mJ}$, cohesiveness sebesar 0.77 dan springiness sebesar $4.19 \mathrm{~mm}$. Penambahan santan kelapa berpengaruh terhadap kadar air dan daya serap minyak donat ( $\alpha=0.05)$, yaitu kadar air $29.48 \%$ dan daya serap minyak $9.31 \%$.
\end{abstract}

Kata kunci: Daya Serap Minyak, Donat, Kadar Air, Kualitas, Santan Kelapa.

\section{ABSTRACT}

Donuts are processed foods made from wheat flour, eggs, sugar, yeast, and margarine that fermented in a certain time and fried with deep frying method. Donuts have shape like a ring. The research method used was Response Surface Method (RSM) one-factor. Studied factor was the concentration of coconut milk addition (X1) and response to be optimized are donuts quality by using hardness measurement (R1), cohesiveness (R2) and springiness (R3) at storage process for 4,24 , and 48 hours. The concentration of coconut milk added is $0 \%$, $15 \%, 30 \%, 45 \%$, and $60 \%$. The results showed that the addition of coconut milk affect donuts quality. The optimum concentration of coconut milk addition was $30.48 \%$ with hardness of $15.62 \mathrm{~mJ}$, cohesiveness of 0.77 and springiness of $4.19 \mathrm{~mm}$. The addition of coconut milk also affected the water content $29.48 \%$ and absorption of donut oil $9.31 \%(\alpha=0.05)$.

Key words: Coconut milk, Donut, Oil Absorption, Quality, Water Content.

\section{PENDAHULUAN}

Donat adalah makanan ringan yang dibuat menggunakan adonan manis melalui proses penggorengan dengan lubang ditengahnya tetapi juga dapat dibuat dalam bentuk bola dan memiliki tekstur yang lembut (BIRT, 2011). Salah satu gerai donat yang populer di Indonesia adalah J.CO Donuts. Properti Data (2016) menyatakan bahwa sejak 10 tahun berdiri J.CO Donuts telah berhasil menjalankan 232 gerai toko di seluruh Indonesia, dimana produksi donat setiap tahunnya mencapai 80.5 juta buah donat. Rata-rata konsumsi donat setiap minggu sebesar 12 buah per orang (Levitt, 2016). 
Donat memiliki beberapa parameter fisik dan kimia yang menjadi acuan mutu dari produk. Permasalahan yang sering terjadi pada produk donat selama proses penyimpanan yaitu terjadinya perubahan pada karakteristik fisik seperti terjadinya staling. Proses staling disebabkan oleh adanya proses retrogradasi pati yang berakibat pada meningkatkan kristalisasi atau keteraturan molekul polimer pati sehingga terjadi peningkatan kekerasan crumb (Aini, 2014).

Salah satu upaya untuk mengurangi potensi terjadinya perubahan tersebut adalah dengan penambahan bahan baku yang mengandung kadar air dan lemak yang cukup tinggi (Lallemand, 2016). Salah satu bahan yang memiliki kadar air dan lemak cukup tinggi adalah santan kelapa. Santan kelapa merupakan emulsi lemak dalam air dan dapat berwarna putih susu karena partikelnya berukuran lebih besar dari satu micron. Kandungan air dalam santan kelapa murni sebesar 54.9 gram sedangkan dalam santan kelapa dengan penambahan air sebesar 80 gram. Untuk kandungan lemak dalam santan kelapa murni sebesar 34.3 gram dan dalam santan kelapa dengan penambahan air sebesar 10 gram (Tangsuphoom dan Coupland 2009). Santan kelapa yang memiliki kandungan gizi dan karakteristik yang hampir sama dengan susu sapi dapat menggantikan peran dari susu sapi pada pembuatan donat, sehingga dapat memperluas tingkat konsumsi masyarakat seperti pada penderita lactose intolerant yang tidak dapat mengonsumsi produk olahan yang mengandung susu sapi. Pemilihan santan kelapa sebagai bahan subsitusi parsial pada donat juga bertujuan sebagai diversifikasi pangan olahan berbasis santan kelapa untuk mendukung swasembada pangan di Indonesia.

\title{
BAHAN DAN METODE
}

\section{Bahan}

Bahan utama yang digunakan untuk pembuatan donat dengan penambahan santan kelapa adalah parutan kelapa tua yang diperoleh dari Pasar Tawangmangu Kota Malang dan tepung terigu protein tinggi (Cakra Kembar, Bogasari) serta bahan tambahan yang digunakan yaitu gula pasir, telur, ragi (Fermipan), garam, margarin, minyak goreng dan air mineral. Adapun bahan untuk proses analisis kimia yaitu, $\mathrm{H}_{2} \mathrm{SO}_{4}$ (Merck), akuades, $\mathrm{NaOH}$ (Merck), $\mathrm{CHCl}_{3}$, alkohol, $\mathrm{HgO}, \mathrm{K}_{2} \mathrm{SO}_{4}, \mathrm{H}_{3} \mathrm{BO}_{3}$ (asam borat), indikator merah metil dan biru metil, enzim pepsin, enzim pankreatin, buffer fosfat, petroleum eter, serta iodin.

\begin{abstract}
Alat
Peralatan yang digunakan pada pembuatan donat dengan bahan tambahan santan kelapa diantaranya yaitu, mixer (Kitchen Aid, Germany), timbangan digital, loyang, kain, gelas ukur, penggorengan, spatula, kompor, dan rolling pin kayu. Alat yang digunakan untuk analisis adalah oven listrik (Memmert), tanur listrik (Thermolyne), kompor listrik (Maspion), soxhlet extractor, kjeldahl destilation unit (Buchi), waterbath (Memmert), desikator (Simax), labu lemak, labu kjeldahl (Buchi), lemari asap, buret, statif, CT3 Texture analyzer (Brookfield Engineering Labs Inc., USA) dengan software TexturePro CT V1.4 Build 17, beaker glass (Pyrex), cawan alumunium, cawan porselen, alumunium foil, wadah plastik bening, mortar, erlenmeyer (Herma), kertas saring, dan spatula.
\end{abstract}

\section{Tahapan Penelitian \\ Penelitian Pendahuluan}

Penentuan konsentrasi tertinggi penambahan santan kelapa serta penyeleksian penambahan ubi kayu pada konsentrasi $0 \% .10 \%, 20 \%, 30 \%, 40 \%, 50 \%, 60 \%, 70 \%$ dan $80 \%$ dengan melihat karakteristik organoleptik yang bertujuan untuk mengetahui kesesuaian produk donat dengan donat komersil dan dapat diterima konsumen. Data didukung dengan hasil analisis fisik, yaitu kekerasan pada donat menggunakan tensile strength, sehingga ditentukan konsentrasi maksimal penambahan santan kelapa sebesar $60 \%$. 


\section{Pembuatan Santan Kelapa}

Pemilihan buah kelapa tua yang berkualitas baik, dibelah menjadi dua dan dibersihkan dari sabut, tempurung dan kulit kelapa lalu dicuci dengan air. Buah kelapa tua yang sudah bersih kemudian diparut menggunakan mesin pemarut kelapa. Kelapa parut ditimbang dan diperas dengan penambahan air dengan perbandingan 1:1, dan disaring dengan kain (Indriani, 2011).

\section{Pembuatan Donat}

Air dan santan kelapa ditimbang sesuai dengan formulasi. Bahan kering yaitu, tepung terigu, gula pasir, dan ragi yang telah ditimbang sesuai formulasi dicampur menggunakan beater mixer dengan speed 1 selama 1 menit. Kuning telur sesuai formulasi dicampur dan diaduk rata menggunakan hook mixer dengan speed 2 selama 2 menit. Margarin dan garam sesuai formulasi ditambahkan dan diaduk menggunakan hook mixer dengan speed 1 selama 1 menit. Air dan santan kelapa sesuai formulasi ditambahkan secara perlahan ke dalam adonan dan diaduk menggunakan hook mixer dengan speed 1 selama 2-4 menit hingga adonan kalis. Adonan donat kemudian ditimbang dengan bobot $40 \mathrm{~g}$ lalu dibulatkan dan diletakkan diatas loyang, selanjutnya ditutup dengan kain basah untuk difermentasi awal selama 60 menit dengan suhu $27-30^{\circ} \mathrm{C}$. Adonan donat yang sudah difermentasi awal kemudian dipipihkan kembali untuk mengeluarkan gas dan dilakukan pembentukan donat. Adonan donat kemudian difermentasi kembali pada $27-30^{\circ} \mathrm{C}$ selama 10 menit. Adonan donat yang sudah difermentasi kedua kemudian digoreng selama 1-2 menit hingga warna kuning kecoklatan dengan suhu $180 \pm 5^{\circ} \mathrm{C}$ menggunakan metode deep frying (Indriani, 2011).

\section{Metode}

Metode penelitian yang digunakan ialah metode Response Surface Method (RSM) dengan desain rancangan one factor. Faktor yang dikaji yaitu konsentrasi penambahan air dan santan kelapa. Variabel bebas yang digunakan adalah konsentrasi penambahan santan kelapa $\left(X_{1}\right)$ dan respon yang akan dioptimasi yaitu hardness $\left(R_{1}\right)$, cohesiveness $\left(R_{2}\right)$ dan springiness $\left(R_{3}\right)$ hasil pengukuran profil tekstur pada donat sebelum dan setelah proses penyimpanan selama 4jam, 24 jam, dan 48 jam yang nantinya akan digunakan sebagai parameter pengukuran staling rate. Konsentrasi penambahan santan kelapa terendah adalah $0 \%$ dan tertinggi adalah $60 \%$. Kemudian rancangan percobaan tersebut dimasukan ke dalam aplikasi Design Expert 10.0.0 dengan 7 run percobaan. Berdasarkan rancangan percobaan yang terbentuk maka didapatkan 5 perlakuan yaitu penambahan donat dengan konsentrasi 0\% (A1); 15\% (A2); 30\% (A3); 45\% (A4), dan 60\% (A5).

Parameter kimia dan fisik yang dianalisis pada perlakuan terbaik adalah kadar air (SNI 01-2891-1992), kadar lemak (AOAC, 2005), kadar protein (AOAC, 2005), kadar abu (AOAC, 2005), kadar karbohidrat (by difference), tekstur profil (kekerasan, recoverable, dan springiness) dengan Brookfield CT3 Texture Analyzer (Faridah, 2015), dan daya serap minyak (AOAC, 1995).

\section{Prosedur Analisis}

Selisih data hasil analisis donat dengan penambahan santan kelapa setelah dan sebelum penyimpanan selama 48 jam menggunakan respon hardness $\left(\mathrm{R}_{1}\right)$, cohesiveness $\left(\mathrm{R}_{2}\right)$ dan springiness $\left(\mathrm{R}_{3}\right)$ diolah menggunakan $R S M$ one factor. Analisis data diawali dengan memilih design yang tepat sesuai nilai $p<0.005$, pemilihan design dilihat berdasarkan nilai PRESS (Predicted Residual Sum of Squares) terendah. Selanjutnya dianalisis ragam (ANOVA) untuk mendapatkan persamaan akhir prediksi konsentrasi penambahan santan kelapa, kemudian akan dicari titik optimum berdasarkan model statistik yang telah ditentukan.

Analisis ragam (ANOVA) juga dilakukan pada data pengamatan daya serap minyak pada donat memenggunakan aplikasi Minitab 17 dengan nilai $p<0.005$ dan dilanjutkan dengan uji BNT untuk mengetahui adanya pengaruh penambahan santan kelapa terhadap kadar air dan daya serap minyak. 


\section{HASIL DAN PEMBAHASAN}

\section{Karakteristik Bahan Baku Santan Kelapa}

Pengujian bahan baku santan kelapa dilakukan untuk mengetahui profil serta karakteristik dari santan kelapa. Pengujian ini dilakukan untuk mengetahui parameter kimia yang dapat berpengaruh pada karakteristik produk akhir donat dengan penambahan santan kelapa yang dihasilkan. Data analisis bahan baku santan kelapa dapat dilihat pada tabel 1.

Tabel 1. Data Analisis Bahan Baku dengan Literatur

\begin{tabular}{lcc}
\hline \multicolumn{1}{c}{ Kadar } & Hasil Analisis (\%) & Literatur (\%) \\
\hline Protein (\%bb) & $0.51 \pm 0.05$ & $1.33^{\mathrm{a}}$ \\
Lemak (\%bb) & $16.15 \pm 0.69$ & $17.00^{\mathrm{a}}$ \\
Air (\%bb) & $82.42 \pm 0.62$ & $79.91^{\mathrm{a}}$ \\
Abu (\%bb) & $0.45 \pm 0.03$ & $0.51^{\mathrm{a}}$ \\
Karbohidrat (\%bb) & $0.48 \pm 0.01$ & $1.25^{\mathrm{a}}$ \\
\hline
\end{tabular}

Keterangan:

1. Setiap data merupakan rerata 3 kali ulangan

2. Angka di belakang simbol \pm merupakan standar deviasi

$\mathrm{a}=$ USDA (2017)

Kadar air yang tinggi pada santan kelapa akan berpengaruh terhadap sifat reologi adonan dan kualitas akhir produk donat dengan penambahan santan kelapa. Karena penambahan santan kelapa telah memberi sedikit jumlah air, maka volume air yang ditambahkan pada adonan akan lebih sedikit jika dibandingkan dengan adonan yang hanya menggunakan tepung terigu saja. Kadar air yang cukup tinggi pada adonan dapat menghambat terjadinya proses staling pada produk roti (Khatkar, 2016).

Kadar lemak pada santan kelapa cukup tinggi sehingga akan menambah kadar lemak pada donat dengan penambahan santan kelapa. Kandungan lemak yang terdapat pada santan kelapa merupakan lemak nabati tak jenuh yang baik untuk kesehatan. Sehingga kandungan lemak pada santan kelapa tersebut tidak memiliki pengaruh yang buruk dan dapat menambah nilai gizi pada produk akhir donat dengan penambahan santan kelapa. Menurut Aini (2014), kandungan lemak dalam adonan akan mempermudah pemotongan produk roti dan juga dapat menahan air, sehingga membuat masa simpan produk lebih panjang dan kulit produk lebih lunak.

Santan kelapa tidak mengandung protein seperti glutenin dan gliadin yang mana kedua protein ini akan bersinergi dengan air membentuk gluten dan memberikan efek viskoelastis pada adonan saat proses mixing. Kandungan protein pada santan kelapa dapat berperan untuk meningkatkan kandungan nutrisi pada donat, selain itu protein juga dapat memerangkap air sehingga menghambat retrogradasi pati dan melunakannya tekstur donat (Aini, 2014).

Kandungan karbohidrat pada santan kelapa akan mempengaruhi sifat fisik dan nilai gizi dari produk akhir donat dengan penambahan santan kelapa. Karbohidrat nantinya akan difermentasi oleh sel khamir Saccharomyces cereviceae, hasil fermentasi akan menghasilkan alkohol dan gas $\mathrm{CO}_{2}$ yang mempengaruhi volume adonan dan flavor (Khatkar, 2016).

\section{Karakteristik Fisik Donat dengan Penambahan Santan Kelapa}

Proses pembuatan donat dengan penambahan santan kelapa dilakukan pada lima proporsi penambahan santan kelapa terhadap air yaitu, $0 \%, 15 \%, 30 \%, 45 \%$, dan $60 \%$. Donat dengan penambahan santan kelapa dengan lima proporsi yang dihasilkan, dilakukan pengujian terhadap profil tekstur yang meliputi hardness, cohesiveness, dan springiness. Waktu pengukuran yang dipilih adalah 4 jam, 24 jam dan 48 jam. Hal ini dilakukan karena diperkirakan akan adanya kenaikan maupun penurunan nilai hardness, cohesiveness, dan springiness pada saat penyimpanan yang dimulai dari jam ke-4. 
Pengukuran profil tekstur atau TPA, pada instrumen sampel diletakkan di antara probe dan bagian bawah instrument (tempat sampel diletakkan), yang kemudian probe bergerak ke bawan dan menekan sampel sehingga didapatkan nilai hardness, cohesiveness, dan springiness yang muncul pada software. Pada pengukuran donat dengan penambahan santan kelapa ini probe yang digunakan adalah TA4/1000 dengan kecepatan probe $5 \mathrm{~mm} / \mathrm{s}$. Berikut adalah hasil dari pengukuran nilai hardness, cohesiveness, dan springiness yang didapatkan:

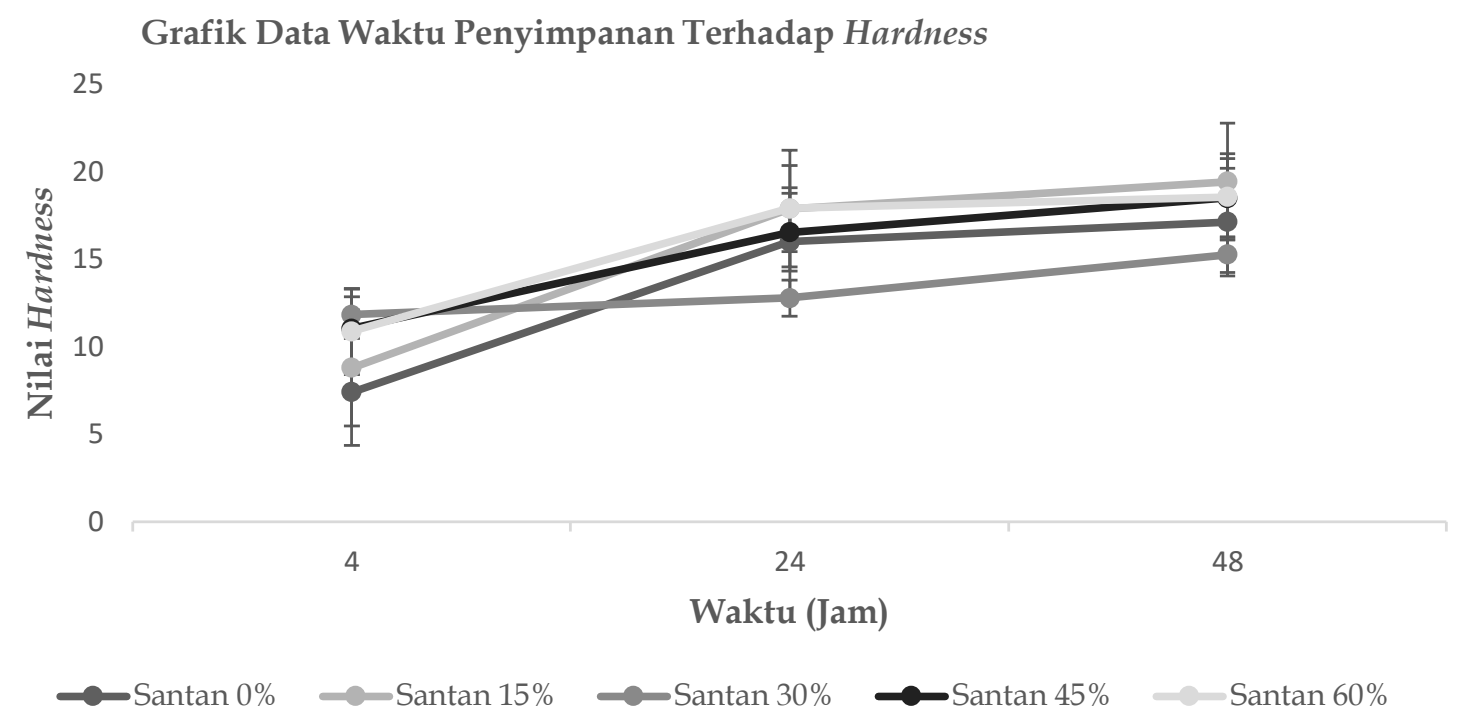

Gambar 1. Grafik Data Waktu Penyimpanan Terhadap Nilai Hardness

Grafik Data Waktu Penyimpanan Terhadap Cohesiveness

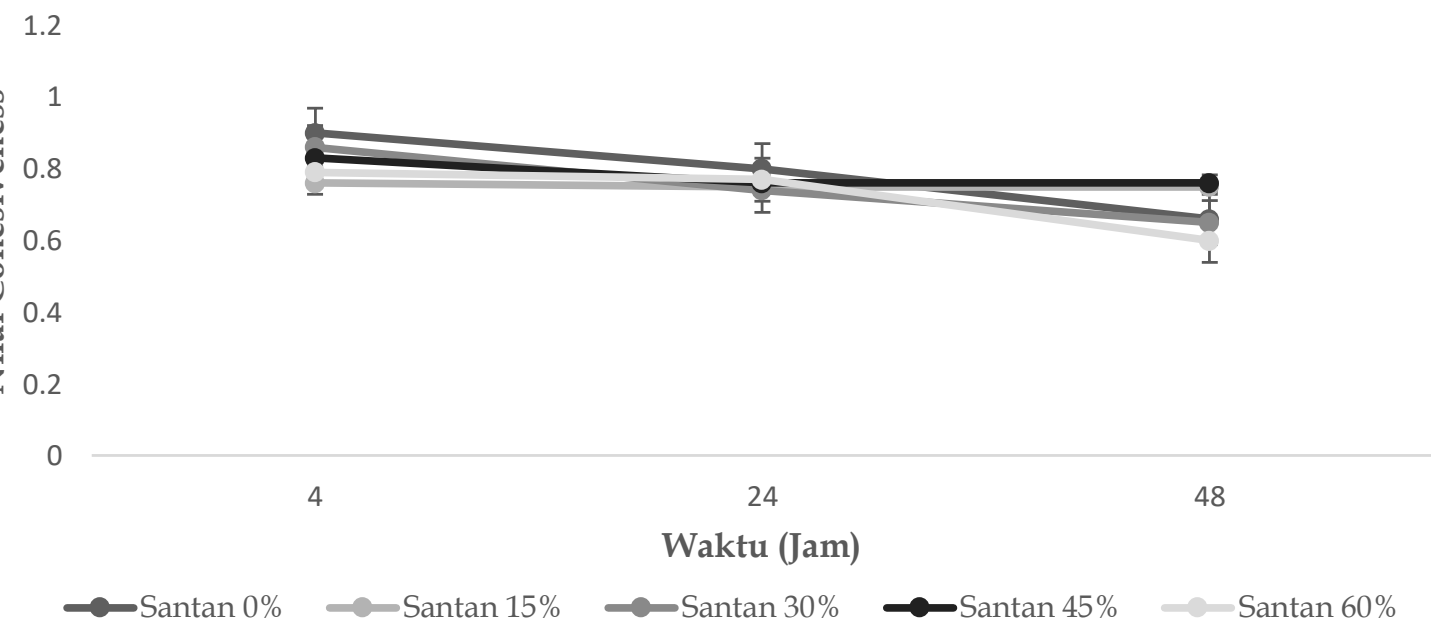

Gambar 2. Grafik Data Waktu Penyimpanan Terhadap Nilai Cohesiveness 
Grafik Data Waktu Penyimpanan Terhadap Springiness

6

5

0

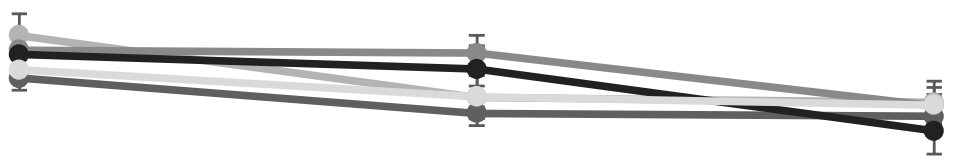

4

24

48

Waktu (Jam)

$\longrightarrow$ Santan $0 \% \quad$ Santan $15 \% \quad$ Santan $30 \%$

$\longrightarrow$ Santan $45 \% \longrightarrow$ Santan $60 \%$

Gambar 3. Grafik Data Waktu Penyimpanan Terhadap Nilai

\section{Daya Serap Minyak Donat}

Daya serap minyak merupakan kemampuan suatu bahan dalam menyerap minyak pada saat proses penggorengan. Jumlah minyak yang terserap tergantung dari perbandingan antara lapisan tengah dan lapisan dalam. Semakin tebal lapisan tengah dan lapisan dalam maka semakin banyak minyak yang terserap. Hasil pengukuran daya serap minyak donat dengan penambahan santan kelapa dengan berbagai konsentrasi yaitu berkisar $5.25-16.73 \%$. Hasil analisis daya serap minyak tersebut dapat dilihat pada Tabel 2.

Hasil analisis ragam menunjukkan bahwa konsentrasi penambahan santan kelapa memberikan pengaruh nyata $(\alpha=0.05)$ terhadap daya serap minyak donat. Daya serap minyak meningkat seiring dengan meningkatnya konsentrasi santan kelapa yang ditambahkan pada donat. Hal ini diduga karena meningkatnya kadar lemak dan kadar air seiring dengan semakin banyaknya konsentrasi santan kelapa yang ditambahkan pada adonan donat. Menurut Dalimunthe dkk. (2012), penyerapan minyak dipengaruhi oleh suhu, lama penggorengan, sifat bahan dan porositas. Kadar air dan kadar lemak yang cukup tinggi pada santan kelapa merupakan salah satu sifat bahan yang dapat meningkatkan daya serap minyak pada donat dengan penambahan santan kelapa.

Tabel 2. Data Hasil Analisis Daya Serap Minyak Donat

\begin{tabular}{ccc}
\hline Konsentrasi Santan Kelapa (\%) & Daya Serap Minyak (\%) & BNT (5\%) \\
\hline 0 & $5.25 \pm 0.83 \mathrm{a}$ & \\
15 & $7.55 \pm 0.43 \mathrm{~b}$ & 1.10 \\
30 & $10.20 \pm 0.72 \mathrm{c}$ & \\
45 & $13.63 \pm 0.57 \mathrm{~d}$ & \\
60 & $16.73 \pm 0.31 \mathrm{e}$ & \\
\hline
\end{tabular}

Keterangan:

1) Setiap data hasil analisis merupakan rerata dari 3 ulangan \pm standar deviasi

2) Angka dengan notasi yang berbeda menunjukkan berbeda nyata $(\alpha=0.05)$

\section{Optimasi Profil Tekstur Donat dengan Penambahan Santan Kelapa}

Berdasarkan pemilihan model untuk respon hardness yang telah dilakukan bahwa model kuadratik adalah model yang disarankan oleh Design Expert 10. Pada respon hardness tidak semua titik residual berada tepat di sepanjang garis tengah, akan tetapi masih disekitar garis tengah. Titik-titik data yang semakin mendekati garis tengah menunjukkan data 
menyebar dengan baik, yang berarti hasil analisis atau hasil aktual yang dilakukan akan tidak jauh berbeda dengan hasil yang diprediksi oleh program (Amalia, 2016). Maka dari itu, hal ini menunjukkan bahwa data yang ada masih dapat terbilang terdistribusi dengan baik dan normal.

Gambar 4 merupakan kurva hubungan antara proporsi santan kelapa yang ditambahkan terhadap hardness donat dengan penambahan santan kelapa. Terjadi penurunan hardness dari proporsi santan kelapa 0\% menuju $45 \%$ dan mencapai minimum pada proprosi santan kelapa $30 \%$. Kemudian setelah itu terjadi kenaikan berturut-turut menuju $45 \%$ hingga proporsi santan kelapa $60 \%$.
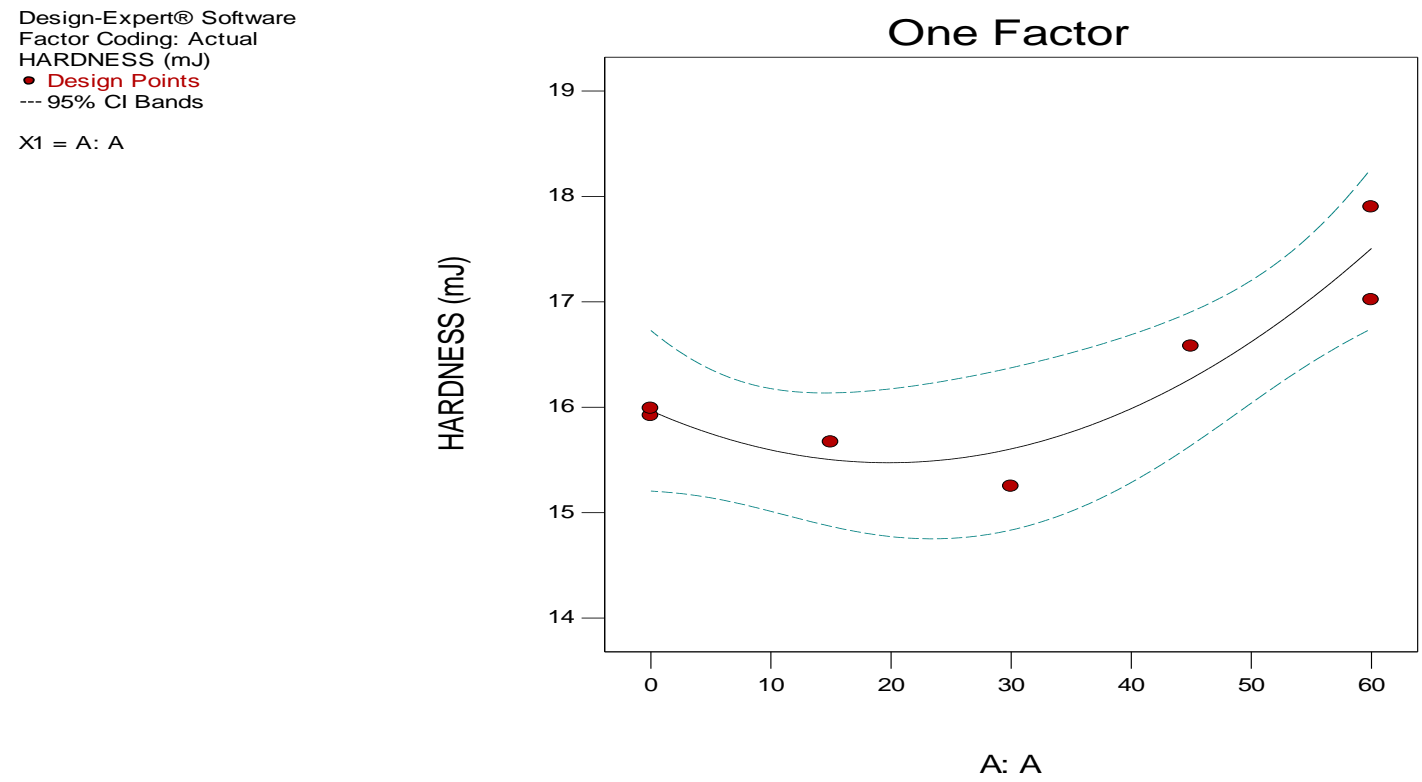

Gambar 4. Kurva Permukaan Respon Variabel Santan Kelapa yang Ditambahkan terhadap Respon Hardness

Menurut Kusnandar (2010), denaturasi protein akibat pemanasan dapat menyebabkan bahan pangan yang mengandung protein mengalami perubahan tekstur, kehilangan daya ikat air, atau mengalami pengkerutan. Kehilangan daya ikat air dapat menyebabkan terjadinya pengerasan selama penyimpanan karena produk akan terpapar udara dan terjadi perubahan suhu lingkungan sehingga memungkinkan terjadinya perubahaan karakteristik menjadi lebih keras yang diakibatkan adanya aktivitas air dari crumb menuju crust (Mirzaei dan Movahed, 2013).

Berdasarkan pemilihan model untuk respon cohesiveess yang telah dilakukan bahwa model kuadratik adalah model yang disarankan oleh Design Expert 10. Sehingga perlu diketahui apakah model kuadratik dapat memberikan pengaruh yang signifikan atau tidak terhadap respon cohesiveness. 


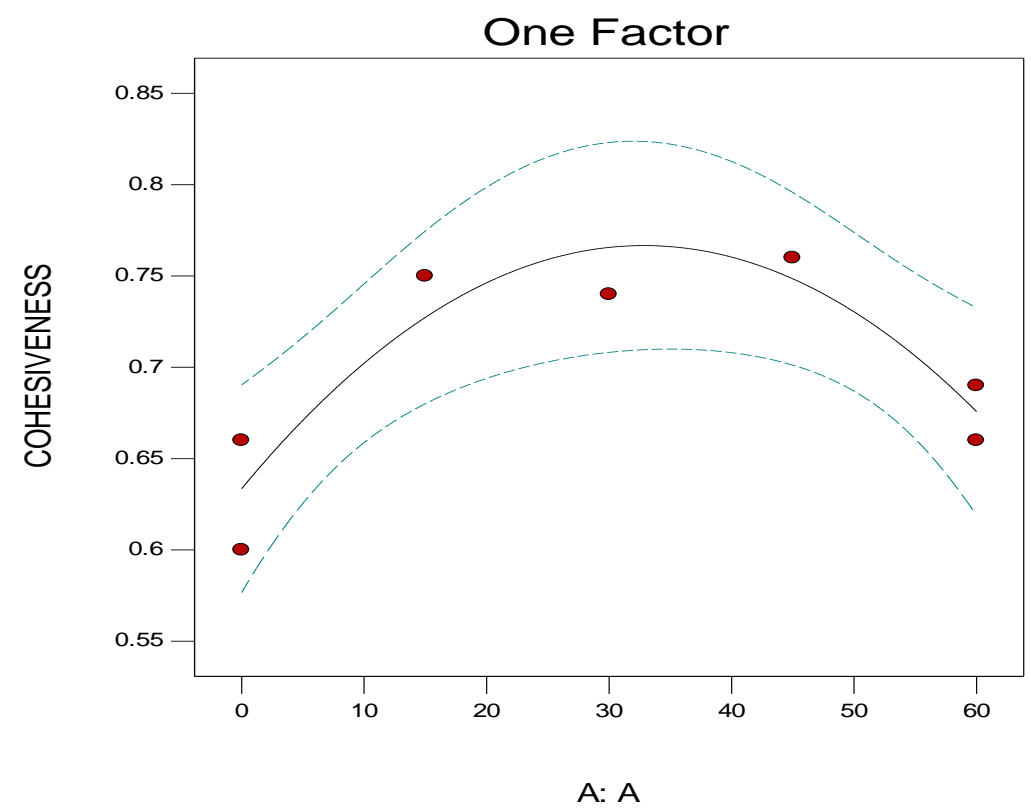

Gambar 5. Kurva Permukaan Respon Variabel Santan Kelapa yang Ditambahkan terhadap Respon Cohesiveness

Gambar 5 diatas merupakan kurva hubungan antara proporsi santan kelapa yang ditambahkan terhadap cohesiveness donat dengan penambahan santan kelapa. Terjadi penurunan hardness dari proporsi santan kelapa $0 \%$ menuju $45 \%$ dan mencapai maksimum pada proprosi santan kelapa $30 \%$. Kemudian setelah itu terjadi penurunan berturut-turut menuju $45 \%$ hingga proporsi santan kelapa $60 \%$.

Berdasarkan pemilihan model untuk respon cohesiveess yang telah dilakukan bahwa model kuadratik adalah model yang disarankan oleh Design Expert 10. Sehingga perlu diketahui apakah model kuadratik dapat memberikan pengaruh yang signifikan atau tidak terhadap respon springiness.

Design-Expert@ Software Factor Coding: Actual

SPRINGINESS (mm

- Design Points

$\mathrm{X} 1=\mathrm{A}: \mathrm{A}$

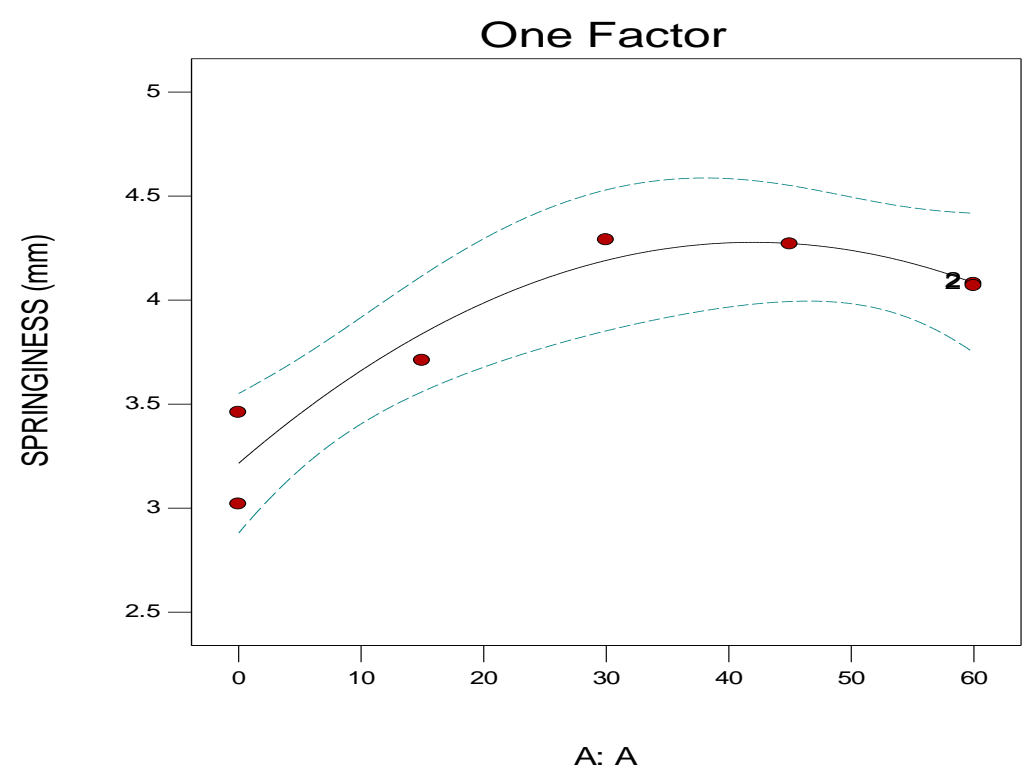

Gambar 6. Kurva Permukaan Respon Variabel Santan Kelapa yang Ditambahkan terhadap Respon Springiness 
Gambar 6 merupakan sebuah kurva hubungan antara proporsi santan kelapa yang ditambahkan terhadap springiness donat dengan penambahan santan kelapa. Terjadi kenaikan springiness dari proporsi santan kelapa $0 \%$ menuju $45 \%$ dan mencapai maksimum pada proprosi santan kelapa $30 \%$. Kemudian setelah itu terjadi penurunan berturut-turut menuju $45 \%$ hingga proporsi santan kelapa $60 \%$.

Kandungan air yang rendah dan perubahan suhu selama penyimpanan akan membuat protein yang ada mengambil air yang dikeluarkan dari pati sehingga menyebabkan perubahaan fraksi pada pati dengan cepat (Khatkar, 2016). Kandungan air yang tinggi menyebabkan aktivitas ragi pada adonan donat meningkat sehingga pembentukan pori pada adonan donat semakin seragam (Khatkar, 2016). Keseragaman pori pada adonan donat membuat donat menjadi semakin kokoh dan elastis sehingga nilai springiness dapat meningkat kembali.

\section{Titik Optimum Profil Tekstur Donat}

Berdasarkan hasil prediksi dari Design Expert 10, dari rentang proporsi santan kelapa $0 \%$ hingga $60 \%$ diperoleh proporsi santan kelapa sebesar $30.48 \%$ yang menghasilkan titik hardness minimum sebesar $15.62 \mathrm{~mJ}$, titik cohesiveness maksimum sebesar 0.77 dan titik springiness maksimum sebesar $4.19 \mathrm{~mm}$ dengan nilai desirability sebesar 0.93 .

\section{Karakteristik Fisik dan Kimia Donat dengan Penambahan Santan Kelapa Perlakuan Terbaik}

Dari hasil verifikasi dari Design Expert 10, telah diambil solusi bahwa konsentrasi santan kelapa $30.48 \%$ merupakan konsentrasi yang optimal untuk dapat menghasilkan hardness yang minimum, cohesiveness yang maksimum, dan springiness yang maksimum pada produk donat dengan penambahan santan kelapa. Konsentrasi santan kelapa tersebut dinyatakan sebagai perlakuan terbaik yang akan diuji lanjut yaitu uji kimia dan uji fisik. Uji kimia yang dilakukan meliputi kadar air, kadar abu, kadar protein, kadar lemak, dan kadar karbohidrat. Sedangkan untuk uji fisik meliputi daya serap minyak, hardness, cohesiveness, dan springiness.

Kadar air dari hasil analisis yang didapatkan sebesar $29.48 \%$, tidak berbeda jauh dengan donat komersial sebesar $28.01 \%$. Perbedaan jenis tepung terigu dari kultivar gandum memungkinkan untuk memberikan hasil absorpsi air yang berbeda. Mis and Dziki (2013) menyatakan gandum kultivar Igna memiliki daya absorpsi air yang tinggi dibandingkan Roma. Kemampuan daya serap air pada terigu akan berkurang bila kadar air terlalu tinggi atau tempat penyimpanan lembab (Bogasari, 2016). Akan tetapi, kadar air produk tersebut masih jauh dibawah batas maksimum SNI (2000) sehingga kadar air produk donat dengan penambahan santan kelapa dapat diterima.

Kadar abu dari hasil analisis menunjukkan pada kisaran $0.85 \%$, lebih rendah jika dibandingkan dengan donat komersial $1.08 \%$. Rendahnya nilai abu dapat disebabkan karena tidak adanya penambahan leavening agent seperti baking powder dan penggunaan hardwater. Progressive Baker (2016) menyatakan bahwa hard-water merupakan air dengan kandungan ion kalsium dan magnesium, tetapi jika kadar terlalu tinggi mampu menghambat proses fermentasi serta menghasilkan adonan yang lengket. Nilai kadar abu hasil analisis masih jauh dibawah batas maksimum SNI sehingga donat dengan penambahan santan kelapa dapat diterima.

Kadar protein hasil analisis produk donat dengan penambahan santan kelapa berada pada angka $6.59 \%$ lebih tinggi jika dibandingkan dengan donat komersial. Nilai ini cukup rendah jika dibandingkan dengan batas normal menurut SNI (01-2000) sebesar $20.8 \%$. Jenis tepung terigu dengan kadar gluten yang berbeda akan menghasilkan kadar protein yang berbeda, Jumlah dan kombinasi dari polipeptida glutenin dan gliadin dari masing-masing varietas gandum akan menentukan tepung terigu yang memiliki kekuatan gluten lebih baik daripada yang lain (Canadian Grain Commission, 2016).

Donat dengan penambahan santan kelapa konsentrasi $30.48 \%$ hasil analisis menunjukkan kadar lemak sebesar $15.38 \%$, lebih rendah jika dibandingkan dengan donat 
komersial $21.82 \%$. Perbedaan ini dapat disebabkan oleh jumlah shortening dan banyaknya minyak yang terserap saat penggorengan. Velez-Ruiz and Sosa-Morales (2003) menambahkan bahwa penggorengan menyebabkan struktur adonan menjadi lebih kompak. Nilai ini masih jauh berada dibawah standar maksimum SNI sebesar 33\% sehingga produk ini dapat diterima.

Tabel 3. Karakteristik Kimia Donat dengan Penambahan Santan Konsentrasi 30,48\%

\begin{tabular}{llll}
\hline \multicolumn{1}{c}{ Parameter } & \multicolumn{1}{c}{ Hasil Analisis } & \multicolumn{1}{c}{ Donat Komersial $^{\mathbf{a}}$} & \multicolumn{1}{c}{ SNI $^{\mathbf{b}}$} \\
\hline Air (\%) & $29.48 \pm 0.07$ & 28.01 & Maks. 40 \\
Abu (\%) & $0.85 \pm 0.01$ & 1.08 & Maks. 7.4 \\
Protein (\%) & $6.59 \pm 0.02$ & 5.45 & Normal 20.8 \\
Lemak (\%) & $15.38 \pm 0.06$ & 21.82 & Maks. 33 \\
Karbohidrat (\%) & $47.71 \pm 0.13$ & 43.64 & - \\
\hline
\end{tabular}

Keterangan:

1. Setiap data merupakan rerata dari 3 kali ulangan

2. Angka di belakang simbol \pm merupakan standar deviasi

3. 'Dunkin' Donuts (sugar raised) (2016)

bSNI (01-2000)

Tabel 4. Karakteristik Fisik Donat dengan Penambahan Santan Konsentrasi 30.48\%

\begin{tabular}{lcc}
\hline Parameter Fisik & Analisis & Literatur \\
\hline Hardness (mJ) & $15.61 \pm 0.28$ & $19.42^{\mathrm{b}}$ \\
Cohesiveness & $0.74 \pm 0.01$ & $1.98^{\mathrm{b}}$ \\
Springiness $(\mathrm{mm})$ & $4.17 \pm 0.06$ & $4.52^{\mathrm{b}}$ \\
Daya serap minyak (\%) & $9.31 \pm 0.004$ & $17.67^{\mathrm{a}}$ \\
\hline
\end{tabular}

Keterangan:

1. Setiap data merupakan rerata dari 3 kali ulangan

2. Terkecuali untuk data hardness, cohesiveness, dan springiness merupakan rerata 2 kali ulangan

3. Angka di belakang simbol \pm merupakan standar deviasi

4. aDalimunthe dkk. (2012)

bSirichokworrakit et al. (2016)

cFAO (2016)

Karakteristik fisik yang dianalisis pada donat dengan penambahan santan kelapa optimum yaitu profil tekstur meliputi hardness, cohesiveness dan springiness. Hasil analisis hardness pada donat dengan penambahan santan kelapa optimum yaitu sebesar $15.61 \mathrm{~mJ}$, lebih rendah dari donat tanpa penambahan santan kelapa yaitu sebesar $19.42 \mathrm{~mJ}$ hal ini disebabkan penambahan bahan yang memiliki kadar air yang cukup tinggi. Profil tekstur selanjutnya yang dianalisis yaitu cohesiveness. Hasil analisis cohesiveness donat dengan penambahan santan kelapa optimum yaitu sebesar 0.74 , lebih rendah jika dibandingkan dengan donat tanpa penambahan santan kelapa yaitu sebesar 1.98. Profil tekstur springiness juga dianalisis pada donat dengan penambahan santan kelapa optimum. Hasil analisis springiness pada donat dengan penambahan santan kelapa sedikit lebih rendah jika dibandingkan dengan donat tanpa penambahan santan kelapa yaitu sebesar $4.17 \mathrm{~mm}$ sedangkan pada donat tanpa penambahan santan kelapa sebesar $4.52 \mathrm{~mm}$.

Nilai daya serap minyak hasil analisis juga sangat berbeda dengan hasil literatur. Hal ini dapat terjadi karena beberapa sebab, yaitu suhu dan lama waktu saat menggoreng, dan jenis minyak yang digunakan untuk menggoreng. Farkas dan Hubbard (2000) menyatakan bahwa proses penggorengan menyebabkan bahan menjadi crisp, crunchy crust, tetapi lembut di dalam crumb. Air akan menguap keatas, menyebabkan crust kering dan tebal. 


\section{SIMPULAN}

Hasil penelitian menunjukkan bahwa penambahan santan kelapa dapat berpengaruh terhadap kualitas donat berdasarkan profil tekstur. Konsentrasi penambahan santan kelapa optimum untuk mendapatkan donat dengan kualitas terbaik adalah sebesar $30.48 \%$ dengan profil tekstur kekerasan sebesar $15.62 \mathrm{~mJ}$, cohesiveness sebesar 0.77 dan springiness sebesar $4.19 \mathrm{~mm}$. Penambahan santan kelapa juga berpengaruh terhadap daya serap minyak donat $(\alpha=0.05)$.

Donat dengan penambahan santan kelapa dengan konsentrasi $30.48 \%$ memiliki karakteristik kimia yaitu kadar air $29.48 \%$, kadar abu $0.85 \%$, kadar protein $6.59 \%$, kadar lemak $15.38 \%$ dan kadar karbohidrat $47.71 \%$ serta memiliki karakter fisik yaitu, daya serap minyak sebesar $9.31 \%$. Kandungan nilai gizi donat dengan penambahan santan kelapa optimum dengan takaran saji 40 gram yaitu memiliki energi sebesar 142 kkal dengan angka kecukupan gizi lemak sebesar $9 \%$, protein $4 \%$ dan karbohidrat $6 \%$.

\section{DAFTAR PUSTAKA}

Amalia, Q. 2016. Optimasi Formula Daging Restrukturisasi dengan Metode Response Surface Methodology (Kajian Konsentrasi Gel Porang dan Karagenan serta Pewarna Angkak). Skripsi.Universitas Brawijaya. Malang.

Aini, N. 2014. Meminimalkan Proses Staling Pada Produk Bakeri. Kulinologi Indonesia 12:6, 27-33

AOAC. 1995. Official Methods of Analysis. Washington, Association of Official Analytical Chemists

AOAC. 2005. Official Methods of Analysis of Association Official Analitical Chemists International 18th Ed. The Association of Official Analytical Chemists. Washington DC

BIRT. 2011. BIRT Cake Doughnuts Information Sheet. http://www.bakeinfo.co.nz/. Tanggal akses: $28 / 07 / 2017$

Bogasari, 2016. About Flour. http://bogasari.com Tanggal akses: 19/10/2017.

Canadian Grain Commission. 2016. Gluten's role in bread baking performance. https://www.grainscanada.gc.ca/fact-fait/gluten-eng.htm. Tanggal akses: 19/10/2017

Dalimunthe, H., Novelina, dan Aisma. 2012. Karakteristik Fisik, Kimia Dan Organoleptik Donat Kentang Ready To Cook Setelah Proses Pembekuan. Agroteknologi. Universitas Andalas. Padang

Dunkin' Donuts. 2016. Dunkin' Donuts: Donuts Nutrition Facts (Sugar Raised). http://www.dunkindonuts.ch/assets/pdf/DD_Ingredients_Donuts.pdf Tanggal akses: 19/10/2017.

FAO. 2016. An Overview of Cassava in Sub-Sharan Africa. http://www.fao.org/docrep/007/. Tanggal akses: 19/10/2017.

Farkas, B.E. and Hubbard, L.J. 2000. Analysis of convective heat transfer during immersion frying. Drying Technology 18:6, 1269-1285.

Faridah, H.M. 2015. Pengaruh Jumlah Air dan Jenis Hidrokoloid terhadap Formula Roti Tawar Mini Bebas Gluten Berbasi Tepung Beras, Pati Jagung, dan Pati Singkong. Institut Pertanian Bogor. Bogor.

Indriani. 2011. Donat Goreng dan Panggang. Gramedia Pustaka Utama. Jakarta

Khatkar, B.S. 2016. Bread Industry and Processes. http://www.ddegjust.ac.in/studymaterial/ pgdbst/. Tanggal akses: 18/06/2017

Kusnandar, F. 2010. Kimia Pangan. PT.Dian Rakyat. Jakarta.

Levitt, S.D. 2016. Bagels and Donuts for Sale: A Case Study in Profit Maximmization. Research in Economics 70: 518-535.

Mirzaei M. and Movahed S. 2013. Evaluation of Staling Rate and Quality of Gluten-Free Toast Breads on Rice Flour Basis. Sciences, Engineering and Technology 5:1, 224-227.

Mis, A. and Dziki D. 2013. Extensograph curve profile model used for characterising the impact of dietary fibre on wheat dough. Journal of Cereal Science 57:3, 471-479. 
ProgressiveBaker. 2016. Bread Troubleshooting Guide. http://progressivebaker.com Tanggal akses: 19/10/2017.

Properti Data. 2016. Dalam 10 Tahun J.Co Jual 805 Juta Donat. https://properti.kompas.com Tanggal akses: 19/10/2017.

Sirichokworrakit, S., Maneewong A., and Klongchai, A. 2016. Effects of partial substitution of wheat flour with riceberry flour on quality of fried donut. Proceeding of Academic World $52^{\text {nd }}$ International Conference. Los Angeles. USA.

SNI (Standar Nasional Indonesia). 2000. Syarat Mutu Donat. 01-2000.

Tangsuphoom, N. and Coupland, J.N. 2009. Effect of Thermal Treatments on the Properties of Coconut Milk Emulsion Prepared with Surface-Active Milk Emulsion. Journal of food Hydrocolloids. 23:7, 1792-1800.

USDA. 2017. Full Report (All Nutrients): 45231787, Pure Coconut Milk, UPC: 073436440030. http://www.ndb.nal.usda.gov/ Tanggal akses: 20/10/2017.

Velez-Ruiz, J.F, and Sosa-Morales, M.E. 2003. Evaluation of physical properties of dough of donuts during deep-fat frying at different temperatures. International Journal of Food Properties 6:2, 341-353. 